\title{
Households' inflation perceptions and expectations: survey evidence from New Zealand
}

\author{
Bernd Hayo $^{1} \cdot$ Florian Neumeier ${ }^{1,2}$
}

Accepted: 26 October 2021 / Published online: 9 November 2021

(c) The Author(s) 2021

\begin{abstract}
In this paper, we study how inflation is viewed by the general population of New Zealand. Based on unique representative survey data collected in 2016 and using descriptive statistics and multivariate regressions, we explore various aspects of how laypersons perceive inflation and form inflation expectations. We focus on how an individual's economic situation, information search and interest in inflation, economic knowledge, and attitudes and values are related to inflation perception and expectation, as well as the individual's reaction to them. We interpret our findings as a clear indication that laypersons' knowledge about inflation is much better described by the imperfect information view prevailing in social psychology than by the rational actor view typically assumed in economics.
\end{abstract}

Keywords Inflation perception · Inflation expectation · New Zealand · Monetary policy $\cdot$ Household survey

JEL E52 $\cdot$ E58 $\cdot$ Z1

\section{Introduction}

In macroeconomics and financial economics, inflation is perceived as playing an important role in saving and spending decisions and studying this role is a lively field of research. However, most of the extant economics literature focuses on how

\footnotetext{
Thanks to two anonymous referees, Christie Smith, and participants at the European Public Choice Conference, Money, Macro and Finance Group Annual Conference as well as at research seminars at the Reserve Bank of New Zealand, and the Universities of Hamburg, Kobe, Marburg, Texas at Dallas, and Toyo for helpful comments. The usual disclaimer applies.

Bernd Hayo

hayo@wiwi.uni-marburg.de

1 Marburg Centre for Institutional Economics (MACIE), School of Business and Economics, University of Marburg, 35032 Marburg, Germany

2 Ifo Institute Munich, CESifo, University of Munich, Munich, Germany
} 
inflation is viewed by professional observers, such as financial market participants. Findings from this literature are frequently generalised to nonprofessional economic actors, particularly consumers. For instance, rational expectation formation can rarely be rejected using financial data (see, e.g., Capistran and Timmermann 2009) and it is then often assumed to hold for private households, too. However, standing in the shadow of this dominating approach in mainstream economics is a small, but active, strand of research that explicitly investigates how inflation is viewed by laypersons. Researchers working in this domain address fundamental questions such as whether and how laypersons actually know about price changes, whether their perception of the inflation rate is confounded by other variables, for example, income, or how they store information about past prices in their long-term memories. This alternative stream of research is interdisciplinary in that relevant work can also be found in the fields of psychology, marketing, learning and information processing, and media studies.

In this paper, we utilise representative survey data collected on our behalf in 2016 by Research New Zealand. Our emphasis is on generating stylised facts about how laypersons think about inflation. Thus, the paper is more closely linked to the psychological literature than to the typical economics literature. We are trying to better understand how laypersons perceive past and future inflation, how they learn about inflation, and how they respond to it.

Several findings emerge. The most important are the following. (i) Although respondents think that they are relatively well-informed about inflation, less than one-half actually know last year's inflation rate. (ii) On average, stated inflation rates are significantly higher than the actual inflation rate. (iii) When recalling inflation rates from last year, people are attracted to natural numbers. (iv) People who remember higher inflation rates are married, reside in towns (rather than cities or villages), and have a desire to be informed about inflation. People remembering lower inflation rates tend to have a high level of subjective and objective macroeconomic knowledge. (v) We find it difficult to explain what type of people actually react to the inflation rate. In our interpretation, economic reaction to inflation is strongly determined by unobservable factors and/or subject to strong idiosyncratic influences. Theoretically relevant economic variables, such as income, wealth, or saver/debtor position, do not appear to play a role. (vi) Only $25 \%$ of New Zealanders form expectations about the future inflation rate, which is not in line with the typical assumption made in macroeconomic models. (vii) Those who obtain their information about the Reserve Bank of New Zealand (RBNZ) from either their bank advisor or another financial-sector source are more likely to form inflation expectations, suggesting that RBNZ's forward guidance may not reach laypersons directly. (viii) Respondents who are not earning their main income on the labour market are even less interested in forming inflation expectations or less likely to react to the expected inflation rate than other groups in society. (ix) The expected inflation rate moves in a one-to-one fashion with the perceived inflation rate from the last period, suggesting that adaptive inflation expectation formation is superior to forward-looking expectation formation when forecasting inflation. (x) That people overestimate the previous inflation rate leads to an overestimation of future inflation. 
Thus, with respect to the population at large, we interpret our results as an indication that laypersons' knowledge about inflation is more in line with the imperfect information view prevailing in social psychology (see, e.g., Williamson and Wearing 1996) than with the rational actor view often assumed in economics.

Section 2 discusses our conceptual framework and the extant literature. In Section 3, we discuss the empirical methodology and the dataset. We study people's perceptions of last year's inflation rate in Section 4. Section 5 is concerned with investigating people's inflation expectations; Section 6 concludes.

\section{Conceptual framework and extant literature}

A good starting point to the relevant literature are two special issues of the Journal of Economic Psychology, the first of which was published in the mid-1980s and the second roughly 20 years later. Wärneryd's (1986) description of the findings from the seven papers in the earlier special issue, as well as his summary of them and the conclusions he draws, leave little doubt that there was a large gap between the way economists thought about the formation of inflation perceptions and expectations compared to the way psychologists viewed it. In contrast, the four papers in the later special issue, briefly summarised by Ranyard (2008), suggest that the field has converged over time, with authors from different fields becoming more open to research conducted outside their usual area of expertise.

We study perceptions and expectations about inflation using unique representative survey data collected about the New Zealand population in 2016. On the one hand, our investigation is explicitly explorative, as we believe that having a better sense of the patterns present in household data is an important undertaking by itself. Using descriptive statistics and data mining, we highlight notable associations in our dataset and uncover potentially interesting relationships. Since our data are exceptionally detailed in terms of the dimensions covered, such as (i) economic situation, (ii) objective and subjective economic knowledge, (iii) institutional and general trust, (iv) interest in and information search on monetary policy, (v) attitudes towards politicians and government, and (vi) socio-demographic and psychological variables, we believe this to be a useful undertaking.

Specific aspects of monetary policy and inflation in New Zealand are discussed in various studies. Buckle (2019) summarises the period of inflation targeting within which our survey took place. Silverstone (2014) presents the results of a survey amongst members of the Reserve Bank of New Zealand from 1987 and finds that there was a preference for a more flexible monetary policy approach than inflation targeting. Based on survey data on New Zealand firms, Kumar et al. (2015) conclude that inflation targeting does not anchor inflation expectations, although firms review their prices at a (median) bi-annual frequency, according to Parker (2017). Karagedikli and McDermott (2018) find a change in the development of inflation expectations and provide evidence of a move towards more backward-looking behaviour in the years immediately preceding our survey.

On the other hand, we empirically test some of the hypotheses put forward in the extant literature. Ranyard et al. (2008) develop a conceptual framework for 


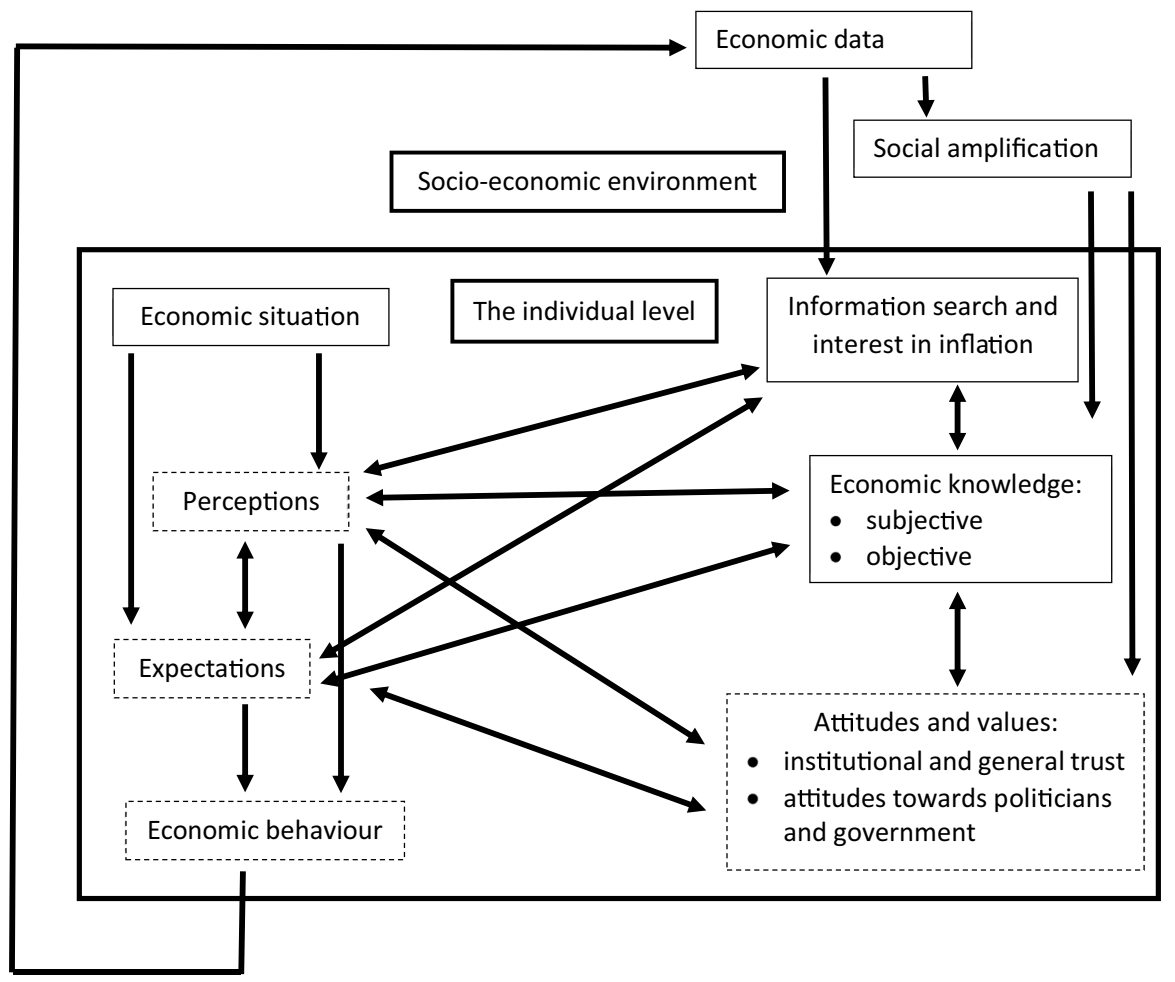

Fig. 1 Extended conceptual framework based on Ranyard et al. (2008)

understanding perceived and expected inflation. We consider this framework a useful starting point for testing some of the proposed relationships using our survey data on New Zealanders. Specifically, we study the impact of variables that are characterised by variation across individuals, as we have only a cross-section of data. Figure 1 takes into account the specific information in our dataset and extends Ranyard et al.'s (2008) conceptual framework. It differentiates two different levels of analysis. One level deals with the macroeconomic environment, consisting of people's impression of the macroeconomy, called 'economic data' here. In addition, we take into account social amplification, particularly through the media, which helps transmit news about the macroeconomy to the individual level. Lamla and Lein (2014) discuss the media's role in consumers' inflation expectation formation. In our framework, this effect would work through economic knowledge, an approach also taken by Hayo and Neuenkirch (2018).

The other level illustrated in Fig. 1 is that of the individual, the level with which we are primarily concerned. Note that manifold socio-demographic and psychological influences are associated with the individual level, but, to preserve readability, we focus on what we believe to be the most important ones. We distinguish between perceptions and expectations using the time dimension: the former are defined as retrospective, that is, they involve the individual's impression of price changes that have already occurred, whereas the latter are defined as prospective, that is, they 
involve price changes that may or may not occur in the future. For instance, Dräger (2015) studies the relationship between inflation perceptions and expectations in Sweden. However, to complicate matters, there is empirical evidence that expectations may feed back into an individual's perception of current or past inflation (Traut-Mattausch et al. 2004).

Compared to Ranyard et al.'s (2008) psychological perspective, we enlarge the number of channels that have the potential to affect inflation expectations. Here, expectations are influenced by the individual's perception of price changes, economic situation, subjective and objective economic knowledge, information search, and interest in inflation and attitudes. The first two aspects are discussed by Ranyard et al. (2008) and the references therein, whereas the latter three channels have not been much addressed and are empirically analysed in this paper.

The concept of economic knowledge can be linked to that of economic literacy, which Jappelli (2010) addresses in a survey context and Burke and Manz (2014) in an experimental setting. The general idea is that the level of economic knowledge is important for both perception and expectation formation. A better state of actual knowledge about the subject matter implies that the individual is more likely to make rational decisions. Such knowledge depends on the individual's information search for and interest in the economic subject matter (Blinder and Krueger 2004; Hayo and Neuenkirch 2018). Most economic studies in the field use representative survey data. Knowledge about the relationship between a policy interest rate and inflation (Carvalho and Nechio 2014), and knowledge about the ECB's policy objectives (van der Cruijsen et al. 2015), as well as knowledge about its transparency practices (van der Cruijsen and Eijffinger 2010), is found to affect inflation expectations. However, there may also be a direct relationship between 'information search and interest in inflation' on the one hand and 'perceptions' and 'expectations' on the other hand. A major driving force would be that the latter is influenced through the process of looking for information, whereas an influence in the opposite direction could be initiated through a specific inflation perception or expectation that leads the individual to acquire more information. Recently, researchers started combining information treatments with survey data to investigate whether informing consumers improves inflation expectations (Haldane and McMahon 2018; Coibion et al. 2019).

Additionally, we study the impact of knowledge on the perception and expectation of inflation. The literature also investigates the relationship between knowledge and attitudes (for a general discussion, see Walstad 1997). Although rare in economics, consumer research explicitly distinguishes between actual or objective knowledge, defined as accurate stored information, and persons' subjective knowledge or their belief about that state of knowledge (e.g., Hadar et al. 2013; Moorman et al. 2004). A situation where subjective knowledge deviates from objective knowledge can lead to decision biases, such as over- or underconfidence.

Inflation perceptions have been studied in various contexts. Of special interest to researchers is the natural experiment of introducing the euro as a new currency, which, on average, led laypersons to overestimate the inflation rate (see, e.g., Greitemeyer et al. 2005; Traut-Mattausch et al. 2004). However, the reverse is found in laboratory experimental evidence based on Swedish students, which suggests that in the case of day-to-day transactions, probands underestimate the actual inflation 
rate (Gärling and Gamble 2008). Also using the introduction of the euro as a sample period and reflecting the interaction between socioeconomic environment and the individual level, Gamble (2006) investigates factors affecting individual perceptions of inflation. The literature contains various interpretations of the differences between laypersons and economists in how they understand inflation. The more social-science-oriented literature is extremely doubtful that there is any similarity between the two groups on this issue. Behrend (1977) suggests that people have an extremely limited understanding of inflation, but other researchers find more encouraging results (e.g., Williamson and Wearing 1996).

The economics literature is also concerned with perceptions of inflation. For example, Dias et al. (2010) discuss the relationship between actual and perceived inflation during the euro changeover. However, there is perhaps a stronger focus on expectation formation. Theoretical models frequently employ the assumption of rational expectations, but the empirical literature is less than sanguine about how rational these expectations really are (see, e.g., Thomas 1999; Berge 2017). For example, there is a notable tendency to underestimate inflation when it is relatively high and to overestimate inflation when it is low. Georganas et al. (2014) provide experimental findings suggesting that inflation perceptions are influenced by the frequency with which prices are observed.

A large part of the literature studies expectation formation by professional forecasters, for example, using the US-based Survey of Professional Forecasters. However, even for these professionals, questions arise with regard to the rational expectations assumption. For instance, Coibion and Gorodnichenko (2015) show that forecast errors made by participants in the Survey of Professional Forecasters underreact to incoming information. Household expectation formation is even less rational, as it changes very sluggishly. This finding is consistent with the view that laypersons do not regularly monitor inflation news (Carroll 2003). Malmendier and Nagel (2016) argue that individuals rely on their own experience with inflation, which implies an overweighting when compared to the available information set on inflation. Thus, age plays a role in expectation formation, as recent inflation experiences will have a relatively greater influence on younger persons' total lifetime inflation experience.

However, some researchers claim that people do have an understanding of macroeconomic issues that is broadly consistent with economic theory. For example, Carvalho and Nechio (2014) report evidence that laypersons behave in line with a Taylor rule, which is a specific type of interest rate rule under which the central bank sets rates conditional on the deviation of the inflation rate from its target and the state of the business cycle. Claus and Nguyen (2018) provide a more nuanced discussion and reject 'homo economicus', but suggest that consumers can coherently evaluate relevant news when forming expectations.

Figure 1 illustrates how attitudes and values influence inflation perception and expectation. For instance, the literature notes that the design and policy of national monetary institutions, and thereby inflation rates, are affected by cultural differences (see Hayo 1998; De Jong 2002). Individual-level studies typically focus on preferences regarding inflation-unemployment trade-offs; for instance, Fischer and Huizinga (1982) study the US and van Lelyveld (1999) investigate the issue for EU 
member countries. Ehrmann et al. (2015) show that households' purchasing attitudes matter for the precision of their inflation expectations. Looking at New Zealand, Hayo and Neumeier (2021) find that the belief that politicians are long-term oriented is positively related to trust in the RBNZ, whereas other potentially relevant attitudes, for example, with regard to the income distribution, have no significant influence. In Fig. 1, such attitudes are affected by other factors, too, particularly individual (personal knowledge) and social factors.

Expectations and perceptions are thought to influence economic behaviour. This is a standard assumption in economics and is implemented, for instance, in various specifications of the Phillips curve (see, e.g., Mankiw 2015). The Philipps curve in the context of New Zealand is discussed in Hargreaves et al. (2006). McDonald (2017) shows that, in recent years, non-tradable inflation is better forecasted by an adaptive version of expectation formation compared to a forwardlooking one. Reflecting these considerations when making its inflation forecasts, the RBNZ now places a greater weight on past inflation (RBNZ 2017, 23). Similar observations are made for other countries; for example, Ehrmann (2015) presents evidence from 11 industrialised countries that price-setting behaviour appears to be more backward looking in times of persistently low inflation. This suggests that economic behaviour is not simply driven by forward-looking expectations, as is sometimes assumed in the literature (see, e.g., Woodford 2003), but that perceptions of current and past inflation may play an important role, too.

\section{Inflation in New Zealand, empirical methodology, and data}

With less than 5 million inhabitants, New Zealand is a rather small country. However, in 1990, it became the first country to explicitly adopt inflation targeting. At the time our survey was conducted, monetary policy was governed by the Policy Targets Agreement (PTA), which, among other things, stated the inflation target. In the PTA relevant for our analysis, the inflation target ranged between 1 and 3\% over the medium term. The general public can form an opinion about the RBNZ's inflation performance by checking comments and discussions found in a variety of media. Of course, people could also check the actual inflation rate to assess the success of inflation targeting. For instance, the current inflation rate is featured prominently on the RBNZ's website (http://www.rbnz.govt.nz). In Fig. 2, we illustrate the inflation rate from the mid-1980s until our survey was conducted.

The inflation moved into the target range only a few years after introducing inflation targeting. Hence, in the recent past, New Zealanders experienced stable and low inflation rates. However, at the end of the sample period, the inflation rate dropped out of the lower end of the target range (0.3\% in 2015).

Our population survey took place between 13 and 30 May 2016 and was conducted by Research New Zealand. Data and survey methodology are described in detail in Hayo and Neumeier (2016). Research New Zealand created a large panel of 25,000 survey participants, which is exclusively used for research. Our sample consists of 1,000 representatively selected persons from the New Zealand population aged 18 or above. Methodologically, the survey was conducted online and based 


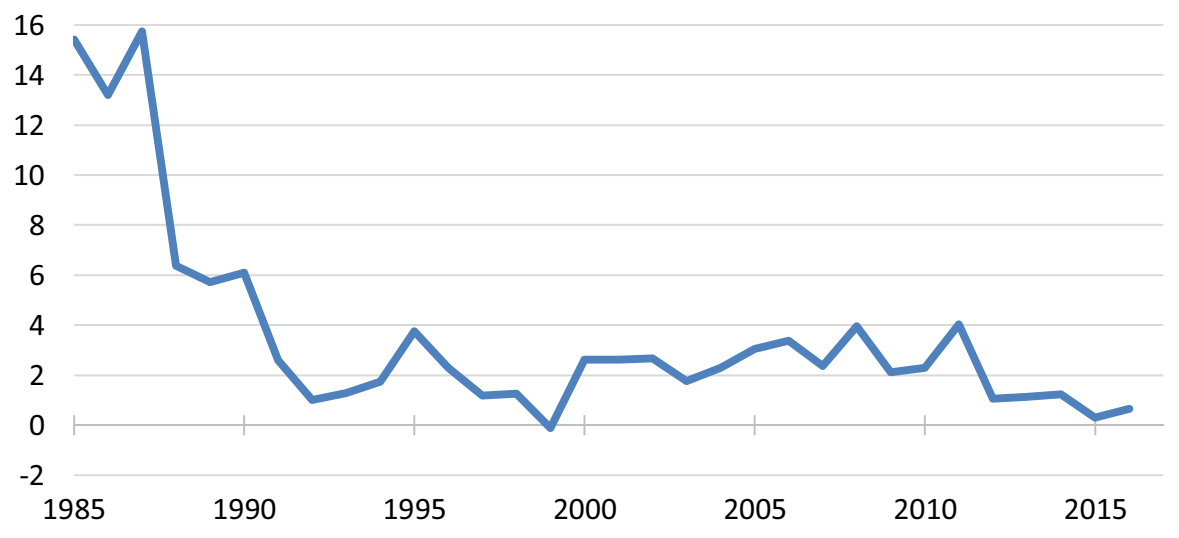

Fig. 2 New Zealand's Inflation History 1985-2016 (annual CPI growth rate in \%). Source: OECD Main Economic Indicators

on quota sampling. For this survey, quotas were initially set on the basis of age, gender, and region. The majority of panellists were recruited after participating in one of Research New Zealand's regular telephone surveys, which helps ensure that the panel also covers those who are less familiar with the Internet. Respondents could choose to opt out of the panel at any time. As an incentive for participation, respondents were given the opportunity to enter a drawing for a prize of NZD 100. Given the close correspondence of the sample to the population, we do not have to use population weights to ensure representativeness.

Designing specific surveys has both advantages and disadvantages. One advantage is that we can ask specific questions pertaining to our research agenda. Moreover, we have an exceptionally broad range of variables at our disposal, which allows controlling for many potentially important influences to an extent far beyond what other studies in the literature have been able to do. A major disadvantage of our dataset is that we do not have a time dimension, implying that we cannot control for the specific economic environment present at the time of data collection. The survey was conducted at a time of unusually low inflation. A general problem with this type of survey-based approach is that it is based on stated, not actual, behaviour and does not easily allow drawing causal conclusions. However, there is some experimental evidence that consumers' inflation expectations have an impact on their choices (Armantier et al. 2015).

In the survey, we were able to include indicators covering all the influences on the 'perceptions box' in Fig. 1, namely:

(i) 'Economic Situation' (measured by: Income, Net personal wealth, Saver, Debtor, Satisfaction with financial situation, Self-employed full time, Self-employed part time, Employed full time, Employed part time, Homemaker, Student, Retired, Unemployed, Beneficiary);

(ii) 'Economic Knowledge' (measured by: Macroeconomic knowledge, Feels informed about RBNZ, Feels informed about inflation, Feels informed about OCR, Heard of PTA); 
(iii) 'Information Search' (measured by: Desire to be informed about RBNZ, Information through newspaper, Information through radio, Information through $\mathrm{TV}$, Information through Internet, Information through friends, Information through colleagues, Information through own bank, Information through financial sector, Does not keep up with RBNZ);

(iv) 'Attitudes and Values' (measured by: Institutional trust, General trust, Politicians act in public's best interest, Politicians long-term oriented, Politicians fiscally competent, Confidence in politicians, Egalitarian attitude, National Party, Labour Party, Green Party, New Zealand First).

(v) We also include socio-demographic and psychological indicators, which control for a number of other influences (Female, Age, Children, Married, Secondary school qualification, Polytechnic qualification or trade certificate, Bachelor's degree or higher, Town, Rural, North Island, Auckland, NZ European, Maori, Asian, Time spent on survey, Risk propensity, Future-oriented time preference, Short-run impatience).

Detailed information about these variables and descriptive statistics can be found in the Appendix.

We use several statistical methods. When analysing inflation expectations, we construct an estimate of a latent variable based on several items by employing nonrotated principal factors (Gorsuch 1983). We apply diagnostic tools, such as scree plots and sampling adequacy tests, and arrive at a factor model with one retained factor. We then construct the factor using regression scoring and interpret it as measuring New Zealanders' economic adjustment to expected inflation.

As estimators, we use standard multivariate ordinary least squares for our continuous dependent variables, such as past and expected inflation rates as well as the factor 'Reaction to expected inflation'. To study the dependent variable 'Inflation expectation formation', which is equal to 1 if a person forms expectations about the inflation rate and 0 otherwise, we use logit regression. Thus, we estimate the following empirical model using maximum likelihood estimation:

$$
\mathrm{ML}=\prod_{i} \frac{e^{X_{i} \beta}}{1+e^{X_{i} \beta}} \prod_{j} \frac{1}{1+e^{X_{i} \beta}},
$$

where $\mathrm{i}$ refers to those who form inflation expectations and $\mathrm{j}$ to those who do not. Matrix X indicates the explanatory variables. We maximise this likelihood with respect to the vector $\beta$ and compute heteroscedasticity-robust standard errors (White 1980).

\section{Perceptions of last year's inflation rate}

First, we analyse the question of how New Zealanders perceive their own knowledge about the inflation rate. In terms of the framework sketched in Fig. 1, we study which variables are associated with the 'perceptions box'. The main influences are the individual's economic situation, economic knowledge, and attitudes and values. Definitions and descriptive statistics of all variables employed here can be found 


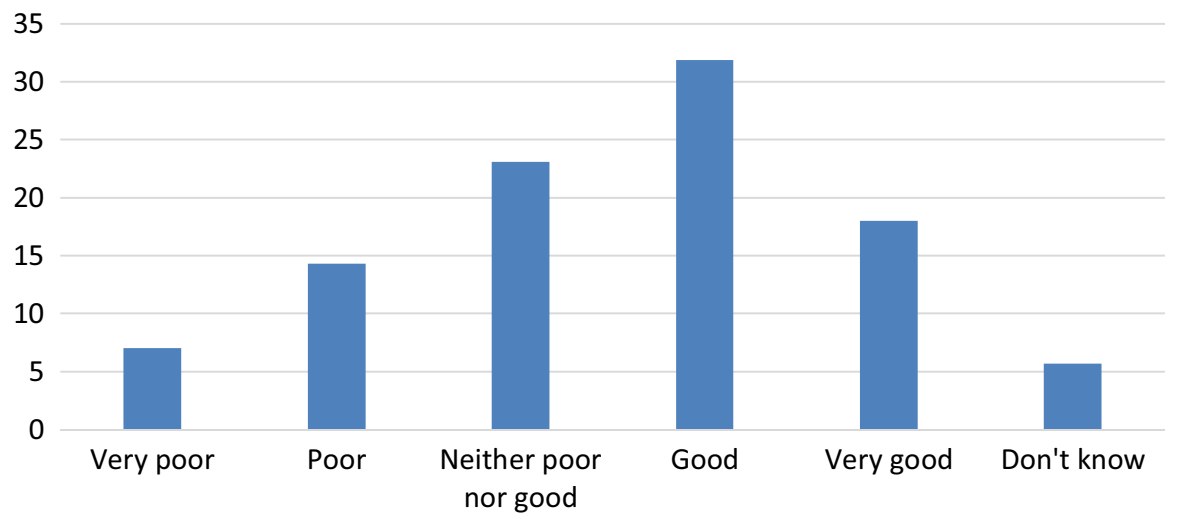

Fig. 3 New Zealanders' subjective knowledge about the inflation rate (in \%)

in the Appendix. We measure subjective knowledge about the inflation based on answers to the question:

How would you rate your level of knowledge of each of these terms?: Inflation rate

Figure 3 shows the resulting distribution of answers. Our respondents seem to be aware of the issue and about 50\% say that their knowledge is good or very good; only about $20 \%$ feel that it is poor or very poor. We would interpret these results as indicating that the concept of inflation is not foreign to New Zealanders.

It is interesting to compare people's subjective knowledge with their objective knowledge. We do that by checking whether our probands can remember last year's inflation rate. Specifically, we asked the following question and code it as a variable called 'Inflation rate last year':

The rate of inflation measures the rate at which the price of goods and services is increasing/decreasing and, therefore, the purchasing power of money. Do you remember what New Zealand's rate of inflation was in 2015? Please write the percentage here

$\square \%$

\section{$\square$ Don't know}

The question is asked in a way that requires a quantitative answer. Moreover, there is no other guidance for the respondents as to what a reasonable inflation rate might be, which makes our question much more demanding than the one often asked in household surveys, namely, whether prices are decreasing or increasing. ${ }^{1}$ Thus,

\footnotetext{
1 For instance, the first question asked about US inflation in the Surveys of Consumers (conducted by the University of Michigan) is: 'During the next 12 months, do you think that prices in general will go up, or go down, or stay where they are now?' (Question A12 in the recent version of the questionnaire; see https://data.sca.isr.umich.edu/fetchdoc.php?docid=24776).
} 
Table 1 Remembering 'Inflation rate last year' (absolute and relative number of respondents)

Provided an answer

$436(44 \%)$
Don't know

$564(56 \%)$

20

15
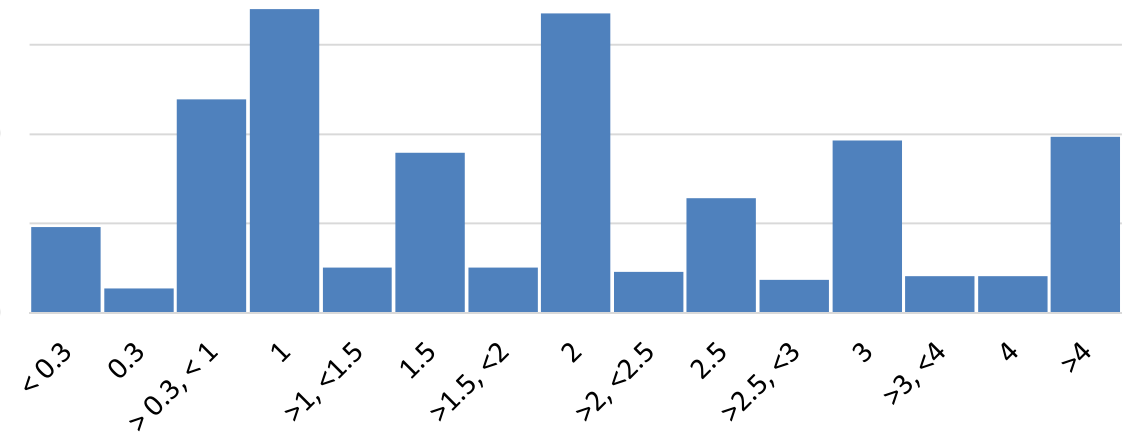

$3 i^{L^{\alpha}} \otimes 7^{\alpha}$

Fig. 4 Summarised distribution of 'Inflation rate last year' (answers in \%)

our approach of asking for an explicit number likely leads to more missing answers than questions of the usual type. However, a major disadvantage of the qualitative type of question is that one needs strong assumptions to translate the answers into numbers. In our case, to make sure that we do not collect 'non-attitudes' (Norpoth and Lodge 1985), we give respondents the option of choosing 'don't know'. Table 1 shows that a majority of our respondents cannot remember the inflation rate or do not feel confident enough to voice an opinion.

The share of 'don't know' answers in our survey is much higher than the approximately $10 \%$ reported in the Michigan Surveys of Consumers in answer to a question about inflation expectations. ${ }^{2}$ One reason for this might be that the Michigan questionnaire contains a sequence of follow-up questions and probes to reduce the number of 'don't knows'. However, such an approach increases the danger that more observations reflecting 'non-attitudes' are collected.

A summary of the distribution of answers from those respondents who stated a value for last year's inflation rate is given in Fig. 4. In 2015, the official inflation rate in New Zealand was $0.3 \%$. Thus, our specific findings may be driven by this situation of very low inflation rates, a situation for which it has been shown that backward-looking behaviour becomes relatively more important than forward-looking behaviour (Ehrmann 2015; McDonald 2017).

Figure 4 reveals several interesting findings. First, whole numbers work as attractors, which is in line with the concept of mental shortcuts (see, e.g., Higbee 2001).

\footnotetext{
${ }^{2}$ See Table 32: 'Expected Change in Prices During the Next Year' (https://data.sca.isr.umich.edu/dataarchive/mine.php).
} 
Second, in contrast, the official rate of inflation does not work as an attractor. We think there are two explanations for this: (i) respondents simply do not know the official inflation rate or (ii) they do not refer to it when answering the question. Put differently, there may be a marked difference between the official inflation rate and the one experienced by an individual respondent. Third, more than two-thirds of the respondents providing a remembered inflation rate chose a number between 1 and $3 \%$, which reflects the range for the inflation rate as agreed to in the PTA. Does that inflation range being selected by our respondents reflect a conscious or an unconscious choice? In our survey, we have a question asking whether New Zealanders have heard of the PTA: only $15 \%$ answer in the affirmative. ${ }^{3}$ Thus, it appears rather unlikely that people cannot remember the official inflation rate but consciously believe that it is still within the target range agreed to in the PTA.

What is the average value for last year's inflation rate when using remembered rates? The arithmetic average is about 4\%, which is 13 times larger than the official value. We showed above that this value is partially driven by large outliers. Using the median instead of the mean halves the inflation rate, that is, we now observe a value of $2 \%$. This value is right in the middle of the PTA range but it is still almost seven times larger than the official inflation rate in 2015. Finally, using the mode as a measure of the average inflation rate, we obtain a value of $1 \%$, which is still three times larger than the official value.

The reason why median and mode yield lower values is their insensitiveness with regard to outliers. A strong justification for excluding outliers would be that they are the result of respondents' coding mistakes, possibly due to too quickly filling out the questionnaire. When investigating this possibility, however, we do not find a noteworthy correlation between the time respondents spent on answering the survey and the value they recorded for 'Inflation rate last year' (correlation coefficient: $-0.01) .{ }^{4}$ Moreover, when correlating the remembered inflation rate with other sociodemographic and attitudinal variables from our survey, the strongest relationship is between people's objective knowledge about macroeconomic developments ('Macroeconomic knowledge': correlation coefficient $=-0.27$ ) and their subjective knowledge ('Feels informed about inflation': correlation coefficient $=-0.26$ ), or, in other words, their own impression of how much they know about the inflation rate. These results suggest reporting a high inflation rate is caused by personal misinformation rather than measurement error.

Due to collinearity between the variables, focusing on bivariate correlations can be highly misleading. Thus, we study the question of whether there are systematic and interpretable factors associated with 'Inflation rate last year' in a multiple regression model. Another approach would be to study the absolute deviations between the remembered inflation rate and the official inflation rate in 2015. This series would look different if a notable share of respondents underpredicted

\footnotetext{
${ }^{3}$ Hayo and Neumeier (2020) provide a deeper discussion of the PTA and central bank independence in New Zealand.

${ }^{4}$ Neither taking logs of time spent on completing the survey nor including an additional squared term of the survey time in a regression leads to a significant relationship.
} 
Table 2 Explaining 'Inflation rate last year'

\begin{tabular}{llll}
\hline & Coefficient & SE & $\begin{array}{r}\text { Coefficient } \\
\text { by std. dev }\end{array}$ \\
\hline Married & $-2.2^{* *}$ & 0.89 & n.a \\
Residing in town & $3.0^{* *}$ & 1.19 & n.a \\
Desire to be informed about RBNZ & $1.5^{* *}$ & 0.61 & 1.5 \\
Feels informed about inflation & $-1.7^{* *}$ & 0.72 & -1.9 \\
Macroeconomic knowledge & $-0.8^{* * *}$ & 0.19 & -1.5 \\
Constant & 8.3 & 2.56 & n.a \\
R $^{2}$ & 0.18 & & \\
Joint significance of covariates & $\mathrm{F}(5,386)=4.8^{* * *}$ & & \\
Regression SE & 6.7 & & \\
Testing-down restriction & $\mathrm{F}(52,330)=0.58$ & & \\
Observations & 392 & & \\
\hline
\end{tabular}

Estimated using OLS. SE= standard error. White (1980) robust SEs are used. For dummy variable reference values, see list of variables in the Appendix. *, **, and *** indicate significance at a $10 \%, 5 \%$, and $1 \%$ level, respectively

the inflation rate. However, this is not the case. The correlation coefficient between this variable and 'Inflation rate last year' is 0.99 and estimation results are virtually identical.

As building blocks for a general model, we include the indicators listed in Section 3. Starting with a model containing these 59 potentially relevant variables, we use general-to-specific modelling to derive the reduced model displayed in Table $2 .{ }^{5}$ When jointly testing the group of excluded variables against zero, we fully take into account possible multicollinearity amongst these variables. This is a much better procedure to assess the consequences of adding many variables in a regression than, say, computing correlation matrices of explanatory variables or VIF values (see Hayo 2018). Although other reduced models are possible, this is the only one where all the remaining variables are statistically significant at the 5\% level. Moreover, as a result of using a consistent general-to-specific modelling approach, there is no specification with only five explanatory variables that dominates this one in terms of explanatory power. As can be seen from the testing-down restriction at the bottom of Table 2, the joint explanatory power of the omitted variables is extremely small $(\mathrm{F}(52,330)=0.58$, the associated p-value is 0.99$)$. Similar arguments apply to the other reduced models presented below.

Following the notable decline in the sample size, we find some noteworthy differences compared to the full sample. In particular, the sample is now skewed towards

\footnotetext{
5 To save space, we omit the table showing the estimates for the general model. Since we find strong evidence of heteroscedasticity (White (1980) heteroscedasticity test for the reduced model: Chi2 $(5)=132 * * *)$, we use robust standard errors (White 1980) throughout the testing-down process. All omitted results are available on request.
} 
Table 3 Do you form opinions about what might be the rate of inflation in the future? (absolute and relative number of respondents)

\begin{tabular}{lll}
\hline Yes & No & Don't know \\
\hline $250(25 \%)$ & $650(65 \%)$ & $100(10 \%)$ \\
\hline
\end{tabular}

respondents who are economically better off, have higher objective and subjective macroeconomic knowledge and interest, higher levels of trust, men, older respondents, NZ Europeans, and spent more time on answering the survey.

Re-estimating the model with 38 additional observations, which have become available as a result of using fewer variables, we find that all the qualitative results remain in place. Based on Table 2, we discover that 'Married', 'Residing in town', 'Desire to be informed about RBNZ', 'Feels informed about inflation', and 'Macroeconomic knowledge' survive the testing-down process. While there is no straightforward explanation for the first three variables, interpretation of the last two significant explanatory variables is easier. They are similar to what we already found when computing correlation coefficients: both subjective and objective knowledge matter for recalling the previous year's inflation rate. A one standard deviation hike in 'Macroeconomic knowledge' decreases the remembered inflation rate by $1.5 \mathrm{pp}$, which means it moves closer to the actual rate. The impact in the case of 'Feels informed about inflation' is even higher: a one standard deviation increase leads to an almost $2 \mathrm{pp}$ lower reported inflation value. The effects are even stronger when we include an interaction term between subjective and objective knowledge. When estimated at the means of the variables, the respective coefficients for subjective and objective knowledge are -2.8 and -2 , compared to -1.7 and -0.8 in Table 2 (results available on request). Thus, our findings clearly suggest that having good objective or subjective economic knowledge leads to a more precise recall of the past inflation rate.

\section{Household inflation expectations}

We now turn to the formation of household inflation expectations. To discover whether expectation formation is a conscious process, we ask our respondents if they form opinions about what might be the rate of inflation in the future. Table 3 shows that only a quarter of the population appears to do so. The vast majority of our respondents do not think about the future inflation rate; $10 \%$ are unsure about the answer to this question.

In our view, this is strong evidence against the idea that people frequently update their beliefs about next year's inflation. Again, the result may be conditional on the low inflation situation present in New Zealand at the time our data were collected.

We would like to learn more about the characteristics of respondents who either do or do not form expectations about the future inflation rate. Again, we investigate these associations in a multivariate framework. As the dependent variable in 
Table 4 Explaining who forms expectations about the future inflation rate

\begin{tabular}{lllll}
\hline & Coefficient & SE & $\begin{array}{l}\text { Average marginal } \\
\text { effects (AME) }\end{array}$ & $\begin{array}{l}\text { AME by } \\
\text { standard } \\
\text { deviation }\end{array}$ \\
\hline Feels informed about RBNZ & $0.23^{*}$ & 0.13 & 0.04 & 0.04 \\
Feels informed about inflation & $0.52^{* * *}$ & 0.11 & 0.08 & 0.09 \\
Desire to be informed about RBNZ & $0.35^{* * *}$ & 0.10 & 0.05 & 0.06 \\
Heard about PTA & $0.64^{* * *}$ & 0.21 & 0.10 & n.a \\
Does not keep up with RBNZ & $-1.02^{* *}$ & 0.51 & -0.16 & n.a \\
RBNZ knowledge from bank advisor & $0.79^{* *}$ & 0.34 & 0.12 & n.a \\
RBNZ knowledge from financial sector & $0.93^{* * *}$ & 0.32 & 0.15 & n.a \\
Retired & $-0.67^{* * *}$ & 0.25 & -0.11 & n.a \\
Self-employed part time & $-1.01^{* *}$ & 0.48 & -0.16 & n.a \\
Beneficiary & $-1.89^{* * *}$ & 0.73 & -0.30 & n.a \\
Homemaker & $-1.26^{* *}$ & 0.62 & -0.20 & n.a \\
Constant & $-4.72^{* * *}$ & 0.51 & & \\
Pseudo-R & & & & \\
Joint significance of covariates & Chi' $(11)=130^{* * *}$ & & \\
Log pseudolikelihood & -384 & & & \\
Testing-down restriction & $\mathrm{F}(49,2.2 \mathrm{E}+08)=0.95$ & & \\
Observations & 807 & & & \\
\hline
\end{tabular}

Estimated using a logit model. White (1980) robust SEs are used. For dummy variable reference values, see list of variables in the Appendix. *, **, and *** indicate significance at a $10 \%, 5 \%$, and $1 \%$ level, respectively

our multivariate logit specification, we use 'Inflation expectation formation', which is equal to 1 if a person forms expectations about the inflation rate and 0 otherwise. Starting with our set of 59 variables, we reduce the model without violating the testing-down restriction. Table 4 presents the estimation results for the simplified model. Most of the effects are significant at a $1 \%$ level, except for 'Feels informed about RBNZ', 'Does not keep up with RBNZ', and 'RBNZ knowledge from bank advisor'.

The first notable result from Table 4 is the association between the subjective knowledge indicators and forming inflation expectations. Those who feel well informed about inflation and the RBNZ are more likely to form expectations. Computing the strength of the relationship in the form of the product of the average marginal effect and a one standard deviation change, we find that the former increases the likelihood of forming inflation expectations by almost $10 \mathrm{pp}$, whereas the latter effect is less than half as large. 'Desire to be informed about RBNZ' and 'Heard about PTA' are also positively associated with forming inflation expectations. A one standard deviation change in the first variable makes it roughly 6 pp more likely to form inflation expectations and if respondents have heard about the PTA, the probability goes up by $10 \mathrm{pp}$. Except for the question on PTA, these variables clearly refer to the individual's subjective mindset; even 'Heard about PTA' contains important characteristics of subjective knowledge. 
Table 5 New Zealanders' reaction to expected inflation (in \%, multiple answers possible)

Question: 'Which of the following does the expected rate of inflation influence, Share Factor loadings if any? Please select as many options as apply'

\begin{tabular}{|c|c|c|}
\hline Your total spending on goods and services & $52 \%$ & 0.62 \\
\hline $\begin{array}{l}\text { How much you spend on food and groceries, clothes, petrol, and other con- } \\
\text { sumables }\end{array}$ & $47 \%$ & 0.74 \\
\hline $\begin{array}{l}\text { How much you spend on white goods, televisions, cars, and other 'big ticket' } \\
\text { items }\end{array}$ & $45 \%$ & 0.70 \\
\hline $\begin{array}{l}\text { How much you spend on eating out, holidays, and other discretionary expendi- } \\
\text { ture }\end{array}$ & $39 \%$ & 0.75 \\
\hline How much you save & $47 \%$ & 0.53 \\
\hline The rate of inflation does not influence how much I save or my spending & $26 \%$ & -0.62 \\
\hline
\end{tabular}

Subsample of 250 observations

The next three significant variables refer to the acquisition of information. Individuals who answer 'Does not keep up with RBNZ' are, unsurprisingly, less likely to form inflation expectations. A change in this dummy variable decreases the likelihood of expectation formation by $16 \mathrm{pp}$. In contrast, those respondents who obtain their information about RBNZ from either their bank advisor or another financial sector source are $12 \mathrm{pp}$ and $15 \mathrm{pp}$, respectively, more likely to form such expectations. This is in line with previous research finding that professional observers put a lot of emphasis on forming as accurate as possible inflation expectations and following forward guidance from a central bank (see Nautz and Strohsal 2015; Hayo and Neuenkirch 2015). Hence, financial market actors seem to be able to impress upon those who seek their advice the importance of forward-looking behaviour, which can be interpreted as supporting the argument made by Carroll (2003). However, in line with findings reported by Johannsen (2014), we find the dispersion of inflation expectations decreases in step with decreases in income and education level, which is not consistent with Carroll's (2003) explanation. ${ }^{6}$

The last group of significant variables encompasses several groups with little labour market involvement. Respondents who fall into one of these categories'Retired', 'Self-employed part time', 'Beneficiary', or 'Homemaker' — are less likely to form inflation expectations. This finding suggests that people who are not the chief labour market earners in their household are not as interested in future inflation as are other groups in society. On the one hand, one can argue that this disinterest is not economically rational, as they would be at least as affected by a higher inflation rate as would most other groups. In fact, some of them may even be more vulnerable, as their income might not be tightly linked to wage growth, which tends to compensate workers for losses in purchasing power. On the other hand, in a low inflation environment, one can afford ignoring the inflation rate without incurring noteworthy economic costs. As argued by Sims (2003) and Caplin and Dean (2015), it can be rational for economic actors not to engage in extensive information gathering.

\footnotetext{
${ }^{6}$ Results available on request.
} 
Table 6 Explaining factor 'Reaction to expected inflation' (reduced model)

\begin{tabular}{|c|c|c|c|}
\hline & Coefficient & SE & $\begin{array}{l}\text { Coeff./std. dev. } \\
\text { of dep. variable }\end{array}$ \\
\hline Auckland & $0.305 * *$ & 0.150 & 0.34 \\
\hline North Island & $0.290 * *$ & 0.142 & 0.32 \\
\hline Patient time preference & $-0.573 * * *$ & 0.217 & $-0.17 \#$ \\
\hline Satisfaction with financial situation & $-0.224 * * *$ & 0.054 & $-0.28 \#$ \\
\hline Politicians act in public's best interest & -0.069 & 0.053 & n.a \\
\hline Information through radio & $-0.334^{*}$ & 0.195 & -0.37 \\
\hline Information through TV & -0.186 & 0.160 & n.a \\
\hline Information through Internet & -0.109 & 0.139 & n.a \\
\hline Information through financial sector & -0.233 & 0.149 & n.a \\
\hline Unemployed & 0.096 & 0.374 & n.a \\
\hline Retired & $0.505^{* *}$ & 0.252 & 0.55 \\
\hline Self-employed full time & $0.557 * *$ & 0.283 & 0.61 \\
\hline Self-employed part time & 0.536 & 0.228 & n.a \\
\hline Employed full time & $0.359 * *$ & 0.365 & 0.59 \\
\hline Employed part time & $0.518 * *$ & 0.257 & 0.57 \\
\hline Beneficiary & $0.726 * *$ & 0.290 & 0.80 \\
\hline Student & $0.570^{* *}$ & 0.282 & 0.63 \\
\hline Time spent on survey & $-0.007 * * *$ & 0.002 & $-0.10 \#$ \\
\hline Constant & 0.825 & 0.352 & n.a \\
\hline $\mathrm{R}^{2}$ & 0.21 & & \\
\hline Joint significance of covariates & $\mathrm{F}(18,228)=6.2 * * *$ & & \\
\hline Testing-down restriction & $\mathrm{F}(41,163)=1.24$ & & \\
\hline Observations & 247 & & \\
\hline
\end{tabular}

Estimated using an OLS model. White (1980) robust SEs are used. \# indicates a standardised regression coefficient. For dummy variable reference values, see list of variables in the Appendix. *, **, and *** indicate significance at a $10 \%, 5 \%$, and $1 \%$ level, respectively

We are interested in discovering how those of our respondents who form inflation expectations react to the expected inflation rate (see Table 5).

With the exception of 'The rate of inflation does not influence how much I save or my spending', we find that the alternatives are chosen by at least $40 \%$ of the respondents. However, we do not find notably different adjustment behaviour to inflation in terms of the type of goods bought or the decision to save.

We employ factor analysis to investigate whether this conclusion holds at the individual level. The Kaiser-Meyer-Olkin measure of sampling adequacy supports our choice (average value of 0.8 and no individual value below 0.77 ) by suggesting that the precondition for conducting a factor analysis is fulfilled and so does the LR test of independence $\left(\mathrm{Chi}^{2}(15)=519\right.$; p-value: 0.000$)$. The scree plot, as well as the difference between the two largest eigenvalues (first eigenvalue: 2.6; second eigenvalue: 0.33), support the existence of one relevant factor. Re-running the factor analysis under the restriction of one factor, we obtain the factor loadings given in the 
last column of Table 5. Factor loadings are high. The signs of the loadings are all positive, except for 'The rate of inflation does not influence how much I save or my spending'. We interpret this factor as measuring New Zealanders' economic adjustment to expected inflation, with higher values indicating a stronger reaction. We call this factor 'Reaction to expected inflation'.

To study conditional correlations between the factor and many respondent characteristics, we estimate a general regression model involving 59 variables and impose a valid testing-down restriction, which yields the reduced model in Table 6. The testing-down restriction refers to the 225 observations employed when estimating the general model. As before in the case of Table 2, the reduction in sample size leads to differences compared to the full sample.

At 0.21 , the coefficient of determination is quite high for a cross-section regression, but even in the reduced model we still include 18 variables, one-third of which are not significant. However, eliminating these variables from the general model would violate the testing-down restriction. ${ }^{7}$ Table 6 sets out the results of re-estimating the reduced model with more than 20 additional observations, available due to including fewer variables. This increases estimation efficiency and allows parameter stability testing, which shows that our estimates are quite stable.

Concentrating on the 11 variables significant at a 5\% level, the following conclusions can be drawn. People living on the North Island react more strongly than those living on the South Island. The magnitude of this association is notable: for inhabitants of the North Island we find an effect on the factor 'Reaction to expected inflation' of more than $30 \%$ of a standard deviation of the dependent variable compared to South Islanders. An even stronger association can be observed for labour market indicators. Those respondents who are active on the labour market tend to have a higher likelihood of reacting to the expected inflation rate.

Three of the remaining variables are continuous variables. Respondents who reported higher values of 'Patient time preference', 'Satisfaction with financial situation', and 'Time spent on survey' are less likely to react to expected inflation. Subjective financial situation has the relatively greatest association with 'Reaction to expected inflation'. Does the size of the expected inflation rate make a difference? The correlation coefficient with the factor 'Reaction to expected inflation' is 0.002 and including the expected inflation rate in the reduced model given in Table 6 shows no significant relationship. Thus, with regard to the impact of inflation expectations on economic action, our results are in contrast to those reported by Armantier et al. (2015).

Figure 5 illustrates the distribution of answers for the expected inflation rate. We find that the arithmetic mean for the expected inflation rate in 2017 is roughly $4 \%$ and the median is $2 \%$. The actual inflation rate in 2017 was about $2 \%$ meaning that, once again, a familiar pattern is revealed: the arithmetic mean overpredicts and the

\footnotetext{
7 The significance of the testing-down restriction including these variables indicates collinearity. However, removing some of them would increase standard errors of other variables, which suggests that standard-error reducing complementarity (Hayo 2018) plays a role, too.
} 


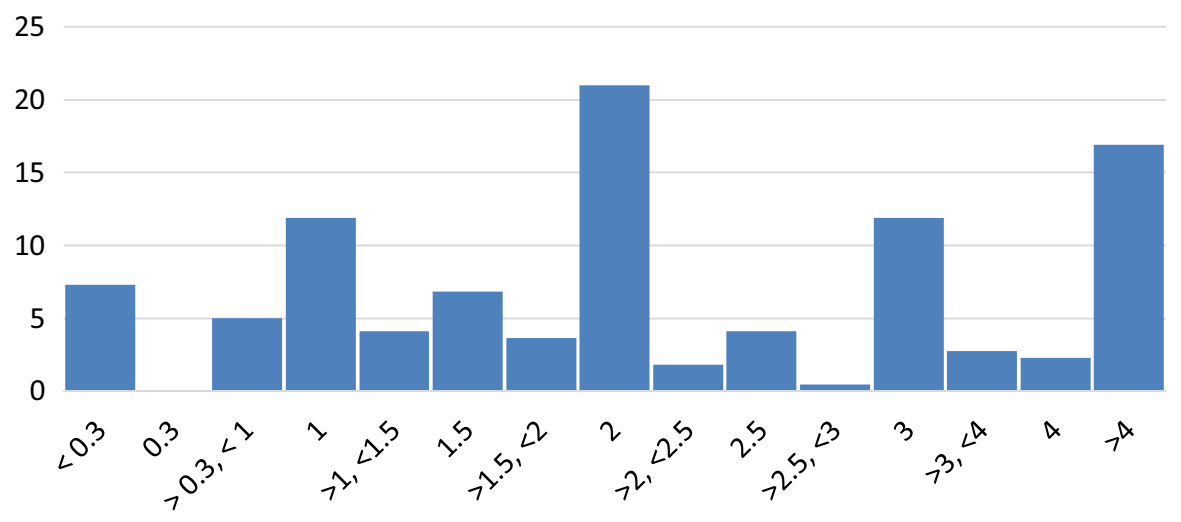

Fig. 5 Summarised distribution of 'Expected inflation rate' (answers in \%)

median is much closer to the actual values. ${ }^{8}$ Interestingly, in terms of correspondence with the official inflation rate, people's inflation predictions turn out to be more precise than their recollection of previous inflation. Typically, it is assumed that it is much more difficult to forecast future inflation than to remember the inflation rate from the previous period.

On behalf of the RBNZ, UMR Research quarterly collects a sample of $750 \mathrm{New}$ Zealanders who are asked about their inflation expectations. ${ }^{9}$ The arithmetic mean based on the answers given in June 2016 for the period until the end of the first quarter in 2017 is 2.2\% and the median 2\% and the answers for 2017 given in December 2016 are 3\% for both mean and median. So while the arithmetic mean in our dataset is larger than in any of these other surveys, our median is very similar to the one based on answers given in June 2016. When comparing this with the Business Survey of Expectations, a New Zealand-wide quarterly survey of business managers and professionals conducted by Nielsen on behalf of the RBNZ, we find a lower average of $1.2 \%$ and $1.9 \%$ for the June and December 2016 survey, respectively. ${ }^{10}$ Thus, as do others, we discover that the population tends to overestimate the inflation rate compared to professional forecasters (see, e.g., Carroll 2003). More generally, there is a longstanding debate in economics about the predictive accuracy of survey-based expectation forecasts. The latest comparison we are aware of is by Berge (2017) over the period 1990-2015 for the US. He comes to a sobering conclusion: 'the surveys, whether used literally or bias-adjusted, do not outperform simple univariate time-series models' (p. 3).

The shape of the expected inflation distribution looks similar to the one describing the perception of past inflation. Hence, the points made in the discussion of Fig. 4 referring to past inflation pertain to expected inflation, too. Figure 5

\footnotetext{
${ }^{8}$ See https://www.rbnz.govt.nz/statistics/key-graphs/key-graph-inflation

9 See https://www.rbnz.govt.nz/statistics/m13 for more details.

10 See https://www.rbnz.govt.nz/statistics/m14 for more details.
} 
Table 7 Explaining 'Expected inflation rate'

\begin{tabular}{llll}
\hline & Coefficient & SE & $\begin{array}{c}\text { Coefficient } \\
\text { by std. dev }\end{array}$ \\
\hline Labour Party & $-1.25^{* *}$ & 0.60 & n.a \\
Beneficiary & $1.18^{* * *}$ & 0.31 & n.a \\
Inflation rate last year & $1.06^{* * *}$ & 0.05 & 8 \\
Constant & $0.94^{* *}$ & 0.48 & n.a \\
$\mathrm{R}^{2}$ & 0.72 & & \\
Joint significance of covariates & $\mathrm{F}(3,165)=141^{* * *}$ & & \\
Regression SE & 5.1 & & \\
White (1980) heteroscedasticity test & $\mathrm{Chi}(5)=3.3$ & & \\
Testing-down restriction & $\mathrm{F}(57,106)=0.62$ & & \\
Observations & 169 & & \\
\hline
\end{tabular}

Estimated using OLS. SE= standard error. White (1980) robust SEs are used. For dummy variable reference values, see list of variables in the Appendix. *, **, and *** indicate significance at a $10 \%, 5 \%$, and $1 \%$ level, respectively

summarises the distribution. The mode of this distribution is $2 \%$ and almost $70 \%$ of the probability mass falls within the PTA range of $1 \%$ to $3 \%$.

Finally, we want to estimate a model that helps us understand which variables are associated with the magnitude of the expected inflation rate. Again, we study these relationships in a multivariate context. Note that we now use 60 variables in the general model, as we additionally include 'Inflation rate last year'. Table 7 contains the reduced model after a consistent testing-down process. Note again the change in the structure of the smaller sample compared to the full sample mentioned in the discussion of Table 2.

Before proceeding with the interpretation, we re-estimate the model in Table 7 using a Heckman-selection specification, conditioning on the variables of the reduced model in Table 4, explaining who forms expectations about the future inflation rate. Mills's lambda is significant at a 5\% level and the variables from Table 7, other than the perceived inflation rate, become insignificant, whereas all variables from Table 4, except 'retired' and 'homemaker', remain significant. We interpret this outcome as supporting our conclusions.

However, the only really robust influence appears to be 'Inflation rate last year'. Put differently, respondents' inflation expectations are not significantly different from their perceived inflation rates in the preceding year. These findings are in line with attempts at modelling expectations at a macroeconomic level in New Zealand. McDonald (2017) provides empirical evidence that non-tradable inflation is better forecast by adaptive expectation formation than it is by forward-looking expectation formation. Thus, at least in this respect, micro-level and macro-level results are consistent. Using survey data on New Zealand firms, Kumar et al. (2015) discover that inflation targeting does not appear to anchor expected inflation rates, which is consistent with our findings for households. 
Our data raise an additional issue. Section 4 shows that respondents overestimate the past inflation rate. In combination with the one-to-one relationship between previous and expected inflation rate, this finding could help explain why households consistently expect a too high inflation rate. However, this only shifts the spotlight from an expectation bias to a perception bias and, given the present dataset, we cannot satisfactorily explain that. Moreover, in line with our conceptual framework in Fig. 1, there may not be a one-directional causal link between the perception of past inflation and the formation of inflation expectations. It could very well be that these are constructed jointly by the respondents at the time they are being asked about the two inflation rates. Put differently, we may be measuring some sort of ad hoc coherency of belief systems that actually reflects some form of nonattitude rather than the response of an informed and rational individual (see Campbell et al. 1960; Zaller 1992).

Comparing our findings with Malmendier and Nagel's (2016) study using timeseries based data, we discover only little evidence to support their suggestion that age plays an important role. We do find a relatively notable negative correlation coefficient between the stated expected inflation value and age $(-0.28)$, suggesting that older respondents have more realistic expectations, but this does not survive in a multivariate context, even when excluding last year's inflation rate.

More generally, socio-demographic influences play a relatively small role in our results. For instance, we do not find any influence of other consumption-relevant variables, such as debtor/saver, income, or wealth, as might be expected when extending the findings by Ehrmann et al. (2015). This conclusion also applies to differences between genders. For instance, Bryan and Venkatu (2001), using data on the US, discover that women report notably higher values for inflation perceptions and expectations than do men. However, in our data, none of the gender effects are statistically significant at a 5\% level. Based on a survey of Dutch households, Christelis et al. (2016) report that trust in the ECB has a negative influence on inflation expectations. We, too, find a negative relation between trust variables and inflation expectations, but it does not survive when controlling for other influences. Thus, it might be the case that some of the findings reported in the extant literature are subject to an omitted variable bias. Alternatively, results may be conditional on the country/region the respective survey has been conducted.

\section{Conclusion}

In this paper, we study how inflation is viewed by the general population of New Zealand. Based on unique representative survey data and using descriptive statistics and multivariate regressions, we explore various aspects of how laypersons perceive inflation and form inflation expectations. Conceptually, our analysis takes place within an extension of a framework put forward by Ranyard et al. (2008). We focus on how an individual's economic situation, information search and interest in inflation, economic knowledge, and attitudes and values are related to inflation perception and expectation. In addition, we control for the possible influence of a large number of socio-demographic and psychological indicators. A major caveat of 
our analysis is that at the time of our survey, the inflation rate in New Zealand was quite low and many of our conclusions may be conditional on this type of economic environment.

Our main findings can be summarised as follows. First, people seem to feel that they are reasonably well-informed about inflation.

Second, people do not accurately remember previous inflation rates. In 2015, the official inflation rate in New Zealand was $0.3 \%$, whereas the arithmetic mean in our sample is about $4 \%$. Overestimation of the inflation rate by laypersons is a rather generally valid finding that is confirmed under extraordinary shocks, for instance, introduction of the euro (e.g., Greitemeyer et al. 2005) as well as normal economic conditions, for instance, as documented for almost any period in the US by the Michigan Surveys of Consumers. We find that when stating inflation rates, people are attracted to natural numbers. In contrast, the official rate of inflation does not work as an attractor. We interpret this set of findings as evidence that people use mental shortcuts when thinking about the inflation rate. More than two-thirds of the respondents remember a number between 1 and 3 per cent, which reflects the range for the inflation rate as agreed to in the Policy Targets Agreement, a unique part of the monetary regime in New Zealand. However, the PTA and the recent monetary reform in New Zealand are further studied in Hayo and Neumeier (2020). Their results suggest little knowledge as well as interest in the actual inflation target and raises doubts about the secure anchoring of inflation expectations at the household level.

Third, we study correlates of remembering high inflation rates and discover that respondents who are married, reside in towns (rather than cities or villages), and have a desire to be informed about inflation rates significantly overpredict the inflation rate. Quite the reverse is found for those having a high level of subjective and objective macroeconomic knowledge. Thus, the results are consistent with the notion that actively monitoring inflation is a precondition for having a relatively precise idea of the inflation rate and stand in contrast to the notion that people unconsciously acquire this information.

Fourth, we discover that only $25 \%$ of New Zealanders form expectations about the future inflation rate. There is a strong association between respondents who feel well informed about inflation and the central bank and those forming expectations. We also find that those who obtain their information about the RBNZ from either their bank advisor or another financial-sector source are more likely to form expectations. This is interesting in that professional observers tend to emphasise understanding the forward guidance provided by central banks and it appears that they are able to convey the importance of this to those laypersons who rely on them for information. Finally, we find evidence that respondents who are not earning their main income on the labour market are even less interested in forming inflation expectations than other groups in society. A similar finding emerges when studying stated economic reactions: respondents involved in labour market activity have a relatively greater likelihood of reacting to the expected inflation rate.

Fifth, the stated expected inflation rate is robustly and significantly related to the perceived inflation rate from last period. The magnitude between the two inflation rates is not significantly different from unity, suggesting that perceived and expected 
inflation rates move in a one-to-one fashion. This micro-level finding is in line with McDonald's (2017) macroeconomic evidence, suggesting that adaptive inflation formation is superior to forward-looking expectation formation when forecasting inflation. Our analysis suggests that combining this result with people's overestimation of past inflation may explain why the extant literature finds that households' inflation expectations are systematically too high (e.g., Carroll 2003). Put differently, using lagged inflation as an indicator for future inflation may actually lead to positively biased predictions.

Thus, with respect to the population at large, we interpret our results as an indication that laypersons' knowledge about inflation is more in line with the imperfect information view prevailing in social psychology (see, e.g., Williamson and Wearing 1996) than with the rational actor view often assumed in economics. For instance, in light of the conclusion by Carvalho and Nechio (2014) that a household's understanding of interest rate decisions can be understood in terms of a Taylor rule, our findings suggest that these conclusions could be spurious and may be the result of putting too much theoretical structure on potentially uninformative empirical data.

As policy conclusions, we would like to suggest that creating more interest in monetary policy, as well as increasing the level of subjective and objective information, may make it more likely that laypersons will behave in ways expected by mainstream economic theory. This implies spending more effort on educating the general population on such matters, which raises issues similar to those discussed in the literature on 'financial literacy' (see, e.g., Lusardi and Mitchell 2014).

\section{Appendix}

Variable descriptions and summary statistics.

\section{Explained variables}

\begin{tabular}{|c|c|c|c|c|c|}
\hline Variable & Coding and Comments & Mean & Std. dev & Min & $\operatorname{Max}$ \\
\hline Inflation rate last year & $\begin{array}{l}\text { Remembered inflation rate for } 2015 \\
\text { in } \%\end{array}$ & 0.15 & 0.36 & 0 & 1 \\
\hline Reaction to expected inflation & $\begin{array}{l}\text { Factor based on various answers to } \\
\text { question: 'Which of the following } \\
\text { does the expected rate of inflation } \\
\text { influence, if any? Please select as } \\
\text { many options as apply' (see Table 6) }\end{array}$ & 0 & 0.91 & -1.3 & 1.3 \\
\hline Inflation expectation formation & $\begin{array}{l}\text { Dummy. Coded } 1 \text { if respondents form } \\
\text { an opinion about inflation in the future }\end{array}$ & 0.25 & 0.43 & 0 & 1 \\
\hline Expected inflation rate & Expected inflation rate for 2017 in $\%$ & 4.32 & 9.75 & -1 & 80 \\
\hline
\end{tabular}

'Inflation rate last year' is also used as an explanatory variable in general model of 'Expected inflation rate' 


\section{Explanatory variables}

\begin{tabular}{|c|c|c|c|c|c|c|c|c|c|}
\hline Variable & $\begin{array}{l}\text { Coding and } \\
\text { Comments }\end{array}$ & Mean & $\begin{array}{l}\text { Std. } \\
\text { dev }\end{array}$ & Min & $\operatorname{Max}$ & $\begin{array}{l}\text { Mean } \\
807 \\
\text { obs }\end{array}$ & $\begin{array}{l}\text { Mean } \\
392 \\
\text { obs }\end{array}$ & $\begin{array}{l}\text { Mean } \\
247 \\
\text { obs }\end{array}$ & $\begin{array}{l}\text { Mean } \\
169 \text { obs }\end{array}$ \\
\hline \multicolumn{10}{|c|}{ (i) 'Economic Situation' } \\
\hline Saver & Dummy & 0.63 & 0.48 & 0 & 1 & 0.66 & 0.74 & 0.71 & 0.77 \\
\hline Debtor & Dummy & 0.30 & 0.46 & 0 & 1 & 0.31 & 0.25 & 0.26 & 0.22 \\
\hline $\begin{array}{l}\text { Satisfac- } \\
\text { tion with } \\
\text { financial } \\
\text { situation }\end{array}$ & $\begin{array}{l}\text { Very dissatisfied } \\
\text { (coded 1) } \\
\text { Dissatisfied } \\
\text { (coded 2) } \\
\text { Neither satisfied } \\
\text { nor dissatis- } \\
\text { fied (coded 3) } \\
\text { Satisfied (coded } \\
\text { 4) } \\
\text { Very satisfied } \\
\text { (coded 5) } \\
\text { Don't know } \\
\text { (coded 3) }\end{array}$ & 3.31 & 1.12 & 1 & 5 & 3.36 & 3.64 & 3.50 & 3.75 \\
\hline $\begin{array}{l}\text { Employed full } \\
\text { time }\end{array}$ & Dummy & 0.38 & 0.49 & 0 & 1 & 0.40 & 0.44 & 0.43 & 0.46 \\
\hline $\begin{array}{l}\text { Employed } \\
\text { part time }\end{array}$ & Dummy & 0.11 & 0.32 & 0 & 1 & 0.12 & 0.10 & 0.11 & 0.09 \\
\hline Homemaker & Dummy & 0.06 & 0.24 & 0 & 1 & 0.06 & 0.02 & 0.02 & 0.01 \\
\hline Student & Dummy & 0.08 & 0.27 & 0 & 1 & 0.07 & 0.05 & 0.07 & 0.06 \\
\hline Retired & Dummy & 0.12 & 0.33 & 0 & 1 & 0.13 & 0.17 & 0.13 & 0.15 \\
\hline Unemployed & Dummy & 0.05 & 0.21 & 0 & 1 & 0.04 & 0.03 & 0.04 & 0.04 \\
\hline Beneficiary & Dummy & 0.04 & 0.20 & 0 & 1 & 0.04 & 0.02 & 0.01 & 0.01 \\
\hline Income & $\begin{array}{l}\text { Per capita } \\
\text { household } \\
\text { income in } \\
\text { NZD1,000. } \\
\text { We added } 184 \\
\text { observations } \\
\text { through } 10 \\
\text { rounds of } \\
\text { imputations } \\
\text { using: Age, } \\
\text { Age squared, } \\
\text { education } \\
\text { dummies, } \\
\text { Saver, Future- } \\
\text { oriented time } \\
\text { preference, } \\
\text { Self-employed } \\
\text { full time, } \\
\text { Employed } \\
\text { full time, } \\
\text { Employed } \\
\text { part time, } \\
\text { Retired, } \\
\text { Student, } \\
\text { Unemployed, } \\
\text { Beneficiary. } \\
\text { Descriptive } \\
\text { statistics for } \\
\text { imputation } 10\end{array}$ & 34.0 & 27.1 & 2.7 & 240 & & Impute & variable & \\
\hline
\end{tabular}




\begin{tabular}{|c|c|c|c|c|c|c|c|c|c|}
\hline Variable & $\begin{array}{l}\text { Coding and } \\
\text { Comments }\end{array}$ & Mean & $\begin{array}{l}\text { Std. } \\
\text { dev }\end{array}$ & Min & Max & $\begin{array}{l}\text { Mean } \\
807 \\
\text { obs }\end{array}$ & $\begin{array}{l}\text { Mean } \\
392 \\
\text { obs }\end{array}$ & $\begin{array}{l}\text { Mean } \\
247 \\
\text { obs }\end{array}$ & $\begin{array}{l}\text { Mean } \\
169 \text { obs }\end{array}$ \\
\hline $\begin{array}{l}\text { Net personal } \\
\text { wealth }\end{array}$ & $\begin{array}{l}\text { In NZD1,000. } \\
\text { We added } 224 \\
\text { observations } \\
\text { through } 10 \\
\text { rounds of } \\
\text { imputations } \\
\text { using: Age, } \\
\text { Age squared, } \\
\text { education } \\
\text { dummies, } \\
\text { Saver, Future- } \\
\text { oriented time } \\
\text { preference, } \\
\text { Self-employed } \\
\text { full time, } \\
\text { Employed } \\
\text { full time, } \\
\text { Employed } \\
\text { part time, } \\
\text { Retired, } \\
\text { Student, } \\
\text { Unemployed, } \\
\text { Beneficiary. } \\
\text { Descriptive } \\
\text { statistics for } \\
\text { imputation } 10\end{array}$ & 35.2 & 88.0 & -375 & 500 & & \multicolumn{2}{|c|}{ Imputed variable } & \\
\hline \multicolumn{10}{|c|}{ (ii) 'Economic Knowledge' } \\
\hline $\begin{array}{l}\text { Macro- } \\
\text { economic } \\
\text { knowledge }\end{array}$ & $\begin{array}{l}\text { The sum of cor- } \\
\text { rect answers } \\
\text { to questions } \\
\text { on the bond } \\
\text { rate, the goal } \\
\text { set in the Fis- } \\
\text { cal Strategy } \\
\text { Report, } \\
\text { debt-to-GDP } \\
\text { ratio, Official } \\
\text { Cash Rate, } \\
\text { main objec- } \\
\text { tive of RBNZ, } \\
\text { independence } \\
\text { of RBNZ } \\
\text { with regard } \\
\text { to interest } \\
\text { rate setting, } \\
\text { interest rate } \\
\text { reaction to } \\
\text { an expected } \\
\text { increase in the } \\
\text { inflation rate, } \\
\text { inflation tar- } \\
\text { get as agreed } \\
\text { in PTA }\end{array}$ & 2 & 1.75 & 0 & 8 & 2.22 & 3.25 & 3.06 & 3.67 \\
\hline $\begin{array}{l}\text { Feels } \\
\text { informed } \\
\text { about } \\
\text { RBNZ }\end{array}$ & $\begin{array}{l}\text { Very poor } \\
\text { (coded 1), } \\
\text { Poor (coded } \\
\text { 2), Neither } \\
\text { poor nor good } \\
\text { (coded 3), } \\
\text { Good (coded } \\
\text { 4), Very good } \\
\text { (coded 5) }\end{array}$ & 2.72 & 0.96 & 1 & 5 & 2.76 & 3.16 & 3.22 & 3.47 \\
\hline
\end{tabular}




\begin{tabular}{|c|c|c|c|c|c|c|c|c|c|}
\hline Variable & $\begin{array}{l}\text { Coding and } \\
\text { Comments }\end{array}$ & Mean & $\begin{array}{l}\text { Std. } \\
\text { dev }\end{array}$ & Min & $\operatorname{Max}$ & $\begin{array}{l}\text { Mean } \\
807 \\
\text { obs }\end{array}$ & $\begin{array}{l}\text { Mean } \\
392 \\
\text { obs }\end{array}$ & $\begin{array}{l}\text { Mean } \\
247 \\
\text { obs }\end{array}$ & $\begin{array}{l}\text { Mean } \\
169 \text { obs }\end{array}$ \\
\hline $\begin{array}{l}\text { Feels } \\
\text { informed } \\
\text { about infla- } \\
\text { tion }\end{array}$ & $\begin{array}{l}\text { Very poor } \\
\text { (coded 1), } \\
\text { Poor (coded } \\
\text { 2), Neither } \\
\text { poor nor good } \\
\text { (coded 3), } \\
\text { Good (coded } \\
\text { 4), Very good } \\
\text { (coded 5) }\end{array}$ & 3.42 & 1.17 & 1 & 5 & 3.50 & 4.10 & 4.07 & 4.28 \\
\hline $\begin{array}{l}\text { Feels } \\
\text { informed } \\
\text { about OCR }\end{array}$ & $\begin{array}{l}\text { Very poor } \\
\quad \text { (coded 1), } \\
\text { Poor (coded } \\
\text { 2), Neither } \\
\text { poor nor good } \\
\text { (coded 3), } \\
\text { Good (coded } \\
\text { 4), Very good } \\
\text { (coded 5) }\end{array}$ & 3.10 & 1.34 & 1 & 5 & 3.17 & 3.82 & 3.79 & 4.08 \\
\hline Heard of PTA & $\begin{array}{l}\text { Dummy. Coded } \\
1 \text { if respond- } \\
\text { ent has } \\
\text { heard of the } \\
\text { Policy Targets } \\
\text { Agreement }\end{array}$ & 0.15 & 0.36 & 0 & 1 & 0.16 & 0.19 & 0.25 & 0.30 \\
\hline
\end{tabular}

(iii) 'Information Search'

\begin{tabular}{|c|c|c|c|c|c|c|c|c|c|}
\hline $\begin{array}{l}\text { Desire to be } \\
\text { informed } \\
\text { about } \\
\text { RBNZ }\end{array}$ & $\begin{array}{l}\text { Not at all } \\
\text { important } \\
\text { (coded 1), } \\
\text { Unimpor- } \\
\text { tant (coded } \\
\text { 2), Neither } \\
\text { important nor } \\
\text { unimportant } \\
\text { (coded 3), } \\
\text { Important } \\
\text { (coded 4), } \\
\text { Very impor- } \\
\text { tant (coded 5), } \\
\text { Don't know } \\
\text { (coded 3) }\end{array}$ & 3.18 & 1.06 & 1 & 5 & 3.22 & 3.56 & 3.68 & 3.79 \\
\hline $\begin{array}{l}\text { Information } \\
\text { through } \\
\text { newspaper }\end{array}$ & Dummy & 0.11 & 0.31 & 0 & 1 & 0.12 & 0.18 & 0.17 & 0.19 \\
\hline $\begin{array}{l}\text { Information } \\
\text { through } \\
\text { radio }\end{array}$ & Dummy & 0.08 & 0.27 & 0 & 1 & 0.09 & 0.14 & 0.12 & 0.15 \\
\hline $\begin{array}{l}\text { Information } \\
\text { through } \\
\text { TV }\end{array}$ & Dummy & 0.18 & 0.39 & 0 & 1 & 0.19 & 0.17 & 0.15 & 0.12 \\
\hline $\begin{array}{l}\text { Information } \\
\text { through } \\
\text { Internet }\end{array}$ & Dummy & 0.22 & 0.42 & 0 & 1 & 0.25 & 0.30 & 0.30 & 0.33 \\
\hline $\begin{array}{l}\text { Information } \\
\text { through } \\
\text { friends }\end{array}$ & Dummy & 0.12 & 0.32 & 0 & 1 & 0.12 & 0.12 & 0.17 & 0.14 \\
\hline $\begin{array}{l}\text { Information } \\
\text { through } \\
\text { colleagues }\end{array}$ & Dummy & 0.07 & 0.26 & 0 & 1 & 0.08 & 0.14 & 0.15 & 0.20 \\
\hline
\end{tabular}




\begin{tabular}{|c|c|c|c|c|c|c|c|c|c|}
\hline Variable & $\begin{array}{l}\text { Coding and } \\
\text { Comments }\end{array}$ & Mean & $\begin{array}{l}\text { Std. } \\
\text { dev }\end{array}$ & Min & Max & $\begin{array}{l}\text { Mean } \\
807 \\
\text { obs }\end{array}$ & $\begin{array}{l}\text { Mean } \\
392 \\
\text { obs }\end{array}$ & $\begin{array}{l}\text { Mean } \\
247 \\
\text { obs }\end{array}$ & $\begin{array}{l}\text { Mean } \\
169 \text { obs }\end{array}$ \\
\hline $\begin{array}{c}\text { Information } \\
\text { through } \\
\text { own bank }\end{array}$ & Dummy & 0.06 & 0.24 & 0 & 1 & 0.06 & 0.08 & 0.11 & 0.12 \\
\hline $\begin{array}{l}\text { Information } \\
\text { through } \\
\text { financial } \\
\text { sector }\end{array}$ & Dummy & 0.06 & 0.24 & 0 & 1 & 0.07 & 0.11 & 0.16 & 0.20 \\
\hline $\begin{array}{l}\text { Does not keep } \\
\text { up with } \\
\text { RBNZ }\end{array}$ & Dummy & 0.12 & 0.32 & 0 & 1 & 0.09 & 0.03 & 0.02 & 0.01 \\
\hline \multicolumn{10}{|c|}{ (iv) 'Attitudes and Values' } \\
\hline $\begin{array}{l}\text { Trust in } \\
\text { RBNZ }\end{array}$ & $\begin{array}{l}\text { 5-point Likert } \\
\text { scale ranging } \\
\text { from (1) 'No } \\
\text { trust and } \\
\text { confidence } \\
\text { at all' to (5) } \\
\text { 'Complete } \\
\text { trust and } \\
\text { confidence'; } \\
\text { Don't know } \\
\text { (coded 3) }\end{array}$ & 3.30 & 0.96 & 1 & 5 & 3.38 & 3.64 & 3.52 & 3.71 \\
\hline $\begin{array}{l}\text { Institutional } \\
\text { trust }\end{array}$ & $\begin{array}{l}\text { Principal } \\
\text { component } \\
\text { based on trust } \\
\text { in govern- } \\
\text { ment, trust in } \\
\text { parliament, } \\
\text { trust in United } \\
\text { Nations, } \\
\text { and trust in } \\
\text { International } \\
\text { Monetary } \\
\text { Fund }\end{array}$ & $-3 e-09$ & 1.55 & -3.50 & 4.38 & 0.05 & 0.22 & 0.05 & 0.19 \\
\hline General trust & Dummy & 0.34 & 0.47 & 0 & 1 & 0.36 & 0.43 & 0.42 & 0.51 \\
\hline $\begin{array}{l}\text { Politicians act } \\
\text { in public's } \\
\text { best interest }\end{array}$ & $\begin{array}{l}\text { 5-point Likert } \\
\text { scale ranging } \\
\text { from (1) } \\
\text { 'Most politi- } \\
\text { cians in New } \\
\text { Zealand serve } \\
\text { the interests } \\
\text { of particular } \\
\text { groups' to (5) } \\
\text { 'Most politi- } \\
\text { cians in New } \\
\text { Zealand act } \\
\text { with the gen- } \\
\text { eral public's } \\
\text { best interests } \\
\text { in mind' }\end{array}$ & 3.02 & 0.93 & 1 & 5 & 3.01 & 3.07 & 3.07 & 3.17 \\
\hline
\end{tabular}




\begin{tabular}{|c|c|c|c|c|c|c|c|c|c|}
\hline Variable & $\begin{array}{l}\text { Coding and } \\
\text { Comments }\end{array}$ & Mean & $\begin{array}{l}\text { Std. } \\
\text { dev }\end{array}$ & Min & Max & $\begin{array}{l}\text { Mean } \\
807 \\
\text { obs }\end{array}$ & $\begin{array}{l}\text { Mean } \\
392 \\
\text { obs }\end{array}$ & $\begin{array}{l}\text { Mean } \\
247 \\
\text { obs }\end{array}$ & $\begin{array}{l}\text { Mean } \\
169 \text { obs }\end{array}$ \\
\hline $\begin{array}{l}\text { Politicians } \\
\text { long-term } \\
\text { oriented }\end{array}$ & $\begin{array}{l}\text { 5-point Likert } \\
\text { scale ranging } \\
\text { from (1) } \\
\text { 'Most politi- } \\
\text { cians are only } \\
\text { concerned } \\
\text { about the } \\
\text { next election' } \\
\text { to (5) 'Most } \\
\text { politicians } \\
\text { are concerned } \\
\text { about New } \\
\text { Zealand's } \\
\text { long-term } \\
\text { well-being' }\end{array}$ & 2.38 & 1.15 & 1 & 5 & 2.34 & 2.43 & 2.37 & 2.38 \\
\hline $\begin{array}{l}\text { Politicians } \\
\text { fiscally } \\
\text { competent }\end{array}$ & $\begin{array}{l}\text { 5-point Likert } \\
\text { scale ranging } \\
\text { from (1) 'The } \\
\text { Government } \\
\text { wastes the } \\
\text { revenue it col- } \\
\text { lects in taxes' } \\
\text { to (5) 'The } \\
\text { Government } \\
\text { conscien- } \\
\text { tiously } \\
\text { manages the } \\
\text { revenue it } \\
\text { collects in } \\
\text { taxes' }\end{array}$ & 2.73 & 1.11 & 1 & 5 & 2.73 & 2.89 & 2.79 & 2.93 \\
\hline $\begin{array}{l}\text { Confidence in } \\
\text { politicians }\end{array}$ & $\begin{array}{l}\text { 5-point Likert } \\
\text { scale ranging } \\
\text { from (1) 'I } \\
\text { do not have } \\
\text { confidence in } \\
\text { New Zealand } \\
\text { politicians' to } \\
\text { (5) 'Overall, } \\
\text { I have } \\
\text { confidence in } \\
\text { New Zealand } \\
\text { politicians' }\end{array}$ & 2.59 & 1.12 & 1 & 5 & 2.58 & 2.76 & 2.66 & 2.75 \\
\hline $\begin{array}{l}\text { Egalitarian } \\
\text { attitude }\end{array}$ & $\begin{array}{l}\text { 5-point Likert } \\
\text { scale ranging } \\
\text { from (1) 'To } \\
\text { encourage } \\
\text { individual } \\
\text { effort, the } \\
\text { difference } \\
\text { between peo- } \\
\text { ple's incomes } \\
\text { should be } \\
\text { greater' to } \\
\text { (5) 'People's } \\
\text { incomes } \\
\text { should be } \\
\text { more equal' }\end{array}$ & 3.32 & 1.20 & 1 & 5 & 3.34 & 3.30 & 3.30 & 3.33 \\
\hline $\begin{array}{c}\text { National } \\
\text { Party }\end{array}$ & Dummy & 0.29 & 0.45 & 0 & 1 & 0.30 & 0.39 & 0.33 & 0.38 \\
\hline Labour Party & Dummy & 0.23 & 0.42 & 0 & 1 & 0.23 & 0.22 & 0.25 & 0.22 \\
\hline Green Party & Dummy & 0.14 & 0.34 & 0 & 1 & 0.14 & 0.12 & 0.14 & 0.13 \\
\hline
\end{tabular}




\begin{tabular}{|c|c|c|c|c|c|c|c|c|c|}
\hline Variable & $\begin{array}{l}\text { Coding and } \\
\text { Comments }\end{array}$ & Mean & $\begin{array}{l}\text { Std. } \\
\text { dev }\end{array}$ & Min & Max & $\begin{array}{l}\text { Mean } \\
807 \\
\text { obs }\end{array}$ & $\begin{array}{l}\text { Mean } \\
392 \\
\text { obs }\end{array}$ & $\begin{array}{l}\text { Mean } \\
247 \\
\text { obs }\end{array}$ & $\begin{array}{l}\text { Mean } \\
169 \text { obs }\end{array}$ \\
\hline $\begin{array}{l}\text { New Zealand } \\
\text { First }\end{array}$ & Dummy & 0.08 & 0.28 & 0 & 1 & 0.09 & 0.09 & 0.10 & 0.09 \\
\hline \multicolumn{10}{|c|}{ (v) 'Socio-Demographic and Psychological indicators' } \\
\hline Female & Dummy & 0.52 & 0.50 & 0 & 1 & 0.50 & 0.39 & 0.39 & 0.31 \\
\hline Age & $\begin{array}{l}\text { 5-year intervals } \\
\text { starting from } \\
18 \text { years }\end{array}$ & 6.58 & 3.33 & 1 & 13 & 6.83 & 7.87 & 7.39 & 7.92 \\
\hline Children & Dummy & 0.31 & 0.46 & 0 & 1 & 0.30 & 0.23 & 0.24 & 0.22 \\
\hline Married & Dummy & 0.62 & 0.48 & 0 & 1 & 0.64 & 0.69 & 0.67 & 0.72 \\
\hline $\begin{array}{l}\text { Secondary } \\
\text { school } \\
\text { qualifica- } \\
\text { tion }\end{array}$ & Dummy & 0.26 & 0.44 & 0 & 1 & 0.25 & 0.19 & 0.23 & 0.22 \\
\hline $\begin{array}{l}\text { Polytechnic } \\
\text { qualifica- } \\
\text { tion or } \\
\text { trade } \\
\text { certificate }\end{array}$ & Dummy & 0.20 & 0.40 & 0 & 1 & 0.20 & 0.20 & 0.16 & 0.15 \\
\hline $\begin{array}{c}\text { Bachelor's } \\
\text { degree or } \\
\text { higher }\end{array}$ & Dummy & 0.41 & 0.49 & 0 & 1 & 0.43 & 0.54 & 0.54 & 0.58 \\
\hline $\begin{array}{l}\text { Self- } \\
\text { employed } \\
\text { full time }\end{array}$ & Dummy & 0.06 & 0.24 & 0 & 1 & 0.06 & 0.08 & 0.10 & 0.10 \\
\hline $\begin{array}{l}\text { Self- } \\
\text { employed } \\
\text { part time }\end{array}$ & Dummy & 0.05 & 0.22 & 0 & 1 & 0.05 & 0.05 & 0.05 & 0.04 \\
\hline Town & Dummy & 0.28 & 0.45 & 0 & 1 & 0.27 & 0.23 & 0.21 & 0.18 \\
\hline Rural & Dummy & 0.20 & 0.40 & 0 & 1 & 0.20 & 0.21 & 0.25 & 0.26 \\
\hline North Island & Dummy & 0.43 & 0.50 & 0 & 1 & 0.43 & 0.41 & 0.45 & 0.44 \\
\hline Auckland & Dummy & 0.32 & 0.47 & 0 & 1 & 0.32 & 0.34 & 0.32 & 0.35 \\
\hline NZ European & Dummy & 0.68 & 0.47 & 0 & 1 & 0.71 & 0.75 & 0.72 & 0.76 \\
\hline Maori & Dummy & 0.04 & 0.19 & 0 & 1 & 0.03 & 0.02 & 0.02 & 0.03 \\
\hline Asian & Dummy & 0.10 & 0.30 & 0 & 1 & 0.10 & 0.09 & 0.11 & 0.10 \\
\hline $\begin{array}{l}\text { Risk propen- } \\
\text { sity }\end{array}$ & $\begin{array}{l}\text { Continuous } \\
\text { variable } \\
\text { that varies } \\
\text { between - } 1 \\
\text { (maximum } \\
\text { risk aversion) } \\
\text { and+1 (maxi- } \\
\text { mum risk } \\
\text { propensity). } \\
\text { We assessed } \\
\text { the inter- } \\
\text { viewees' risk } \\
\text { preferences by } \\
\text { confronting } \\
\text { the inter- } \\
\text { viewees with } \\
\text { the choice } \\
\text { of either } \\
\text { receiving a } \\
\text { safe payoff or } \\
\text { taking part in } \\
\text { a lottery }\end{array}$ & 0.03 & 0.65 & -1 & 1 & 0.03 & 0.01 & 0.02 & 0.04 \\
\hline
\end{tabular}




\begin{tabular}{|c|c|c|c|c|c|c|c|c|c|}
\hline Variable & $\begin{array}{l}\text { Coding and } \\
\text { Comments }\end{array}$ & Mean & $\begin{array}{l}\text { Std. } \\
\text { dev }\end{array}$ & Min & Max & $\begin{array}{l}\text { Mean } \\
807 \\
\text { obs }\end{array}$ & $\begin{array}{l}\text { Mean } \\
392 \\
\text { obs }\end{array}$ & $\begin{array}{l}\text { Mean } \\
247 \\
\text { obs }\end{array}$ & $\begin{array}{l}\text { Mean } \\
169 \text { obs }\end{array}$ \\
\hline $\begin{array}{l}\text { Future-ori- } \\
\text { ented time } \\
\text { preference }\end{array}$ & $\begin{array}{l}\text { Continuous } \\
\text { variable run- } \\
\text { ning from 0 } \\
\text { (completely } \\
\text { impatient) to } \\
1 \text { (completely } \\
\text { patient). Two } \\
\text { experiments } \\
\text { are conducted } \\
\text { to assess the } \\
\text { respondents' } \\
\text { time prefer- } \\
\text { ences in order } \\
\text { to account for } \\
\text { the fact that } \\
\text { many people } \\
\text { are more } \\
\text { patient in the } \\
\text { long run than } \\
\text { in the short } \\
\text { run }\end{array}$ & 0.61 & 0.28 & 0.29 & 1 & 0.61 & 0.64 & 0.66 & 0.68 \\
\hline $\begin{array}{l}\text { Short-run } \\
\text { impatience }\end{array}$ & $\begin{array}{l}\text { Continuous } \\
\text { variable run- } \\
\text { ning from 0 } \\
\text { (completely } \\
\text { impatient) to } \\
1 \text { (completely } \\
\text { patient). Two } \\
\text { experiments } \\
\text { are conducted } \\
\text { to assess the } \\
\text { respondents' } \\
\text { time prefer- } \\
\text { ences in order } \\
\text { to account for } \\
\text { the fact that } \\
\text { many people } \\
\text { are more } \\
\text { patient in the } \\
\text { long run than } \\
\text { in the short } \\
\text { run }\end{array}$ & 0.56 & 0.27 & 0.29 & 1 & 0.56 & 0.60 & 0.60 & 0.63 \\
\hline $\begin{array}{l}\text { Time spent on } \\
\text { survey }\end{array}$ & $\begin{array}{l}\text { Time respond- } \\
\text { ent needed } \\
\text { to fill out the } \\
\text { questionnaire } \\
\text { (in hours) }\end{array}$ & 1.62 & 11.3 & 0.06 & 194 & 1.80 & 2.60 & 2.08 & 2.32 \\
\hline
\end{tabular}

Funding Open Access funding enabled and organized by Projekt DEAL.

Open Access This article is licensed under a Creative Commons Attribution 4.0 International License, which permits use, sharing, adaptation, distribution and reproduction in any medium or format, as long as you give appropriate credit to the original author(s) and the source, provide a link to the Creative Commons licence, and indicate if changes were made. The images or other third party material in this article are included in the article's Creative Commons licence, unless indicated otherwise in a credit line to the material. If material is not included in the article's Creative Commons licence and your intended use is not permitted by statutory regulation or exceeds the permitted use, you will need to obtain permission 
directly from the copyright holder. To view a copy of this licence, visit http://creativecommons.org/licen ses/by/4.0/.

\section{References}

Armantier O, de Bruin WB, Topa G, van der Klaauw W, Zafar B (2015) Inflation expectations and behavior: do survey respondents act on their beliefs? Int Econ Rev 56:505-536

Behrend H (1977) Research into inflation and conception of earnings. J Occup Psychol 50:169-176

Berge TJ (2017) Understanding Survey Based Inflation Expectations, Finance and Economics Discussion Series 2017-046. Board of Governors of the Federal Reserve System, Washington

Blinder AS, Krueger AB (2004) What does the public know about economic policy, and how does it know it? Brook Pap Econ Act 1:327-387

Bryan MF, Venkatu G (2001) The Demographics of Inflation Opinion Surveys, Economic Commentary, Federal Reserve Bank of Cleveland, October

Buckle R (2019) New Zealand's thirty-year experience with inflation targeting: the origins, evolution and impact of a monetary policy innovation. Hist Econ Rev 73:47-84

Burke MA, Manz M (2014) Economic literacy and inflation expectations: evidence from a laboratory experiment. J Money Credit Bank 46:1421-1456

Campbell A, Converse PE, Miller WE, Stokes DE (1960) The American Voter. John Wiley, New York

Capistran C, Timmermann A (2009) Disagreement and biases in inflation expectations. J Money Credit Bank 41:365-396

Caplin A, Dean M (2015) Revealed preferences, rational inattention, and costly information acquisition. Am Econ Rev 105:2183-2203

Carroll CD (2003) Macroeconomic expectations of households and professional forecasters. Quart J Econ 118:269-298

Carvalho C, Nechio F (2014) Do people understand monetary policy? J Monet Econ 66:108-123

Christelis D, Georgarakos D, Jappelli T, van Rooij M (2016) Trust in the Central Bank and Inflation Expectations, DNB Working Paper 496, Amsterdam

Claus E, Nguyen VH (2018) Consumptor economicus: how do consumers form expectations on economic variables? J Econ Behav Organ 152:254-275

Coibion O, Gorodnichenko Y (2015) Information rigidity and the expectations formation process: a simple framework and new facts. Am Econ Rev 105:2644-2678

Coibion O, Gorodnichenko Y, Weber M (2019) Monetary Policy Communications and Their Effects on Household Inflation Expectations, NBER Working Paper 25482

De Jong E (2002) Why are price stability and statutory independence of central banks negaticely correlated? The role of culture. Eur J Polit Econ 18:675-694

Dias F, Duarte C, Rua A (2010) Inflation (Mis)perceptions in the Euro area. Empir Econ 39:353-369

Dräger L (2015) Inflation perceptions and expectations in Sweden—are media reports the 'missing link'? Oxford Bull Econ Stat 77:681-700

Ehrmann M (2015) Targeting inflation from below: how do inflation expectations behave? Int J Cent Bank 8:137-165

Ehrmann M, Pfajfar D, Santoro E (2015) Consumers' Attitudes and Their Inflation Expectations, Finance and Economics Discussion Series 2015-015. Board of Governors of the Federal Reserve System, Washington

Fischer S, Huizinga J (1982) Inflation, unemployment, and public Oopinion polls. J Money Credit Bank 14:1-19

Gamble A (2006) Euro illusion or the reverse? Effects of currency and income on evaluation of consumer prices. J Econ Psychol 27:531-542

Gärling T, Gamble A (2008) Perceived inflation and expected future prices in different currencies. J Econ Psychol 29:401-416

Georganas S, Healy P, Li N (2014) Frequency bias in consumers' perceptions of inflation: an experimental study. Eur Econ Rev 67:144-158

Gorsuch RL (1983) Factor Analysis. Lawrence Erlbaum Associates, Mahwah

Greitemeyer T, Schultz-Hardt S, Traut-Mattausch E, Frey D (2005) The influence of price trend expectations on price trend perceptions: why the euro seems to make life more expensive? J Econ Psychol 26:541-548 
Hadar L, Sood S, Fox CR (2013) Subjective knowledge in consumer financial decisions. J Mark Res 50:303-316

Haldane A, McMahon M (2018) Central bank communications and the general public. Am Econ Rev Pap Proc 108:578-583

Hargreaves D, Kite H, Hodgetts B (2006) Modelling New Zealand Inflation in a Phillips Curve, Reserve Bank of New Zealand Bulletin 69, Wellington

Hayo B (1998) Inflation culture, central bank independence and price stability. Eur J Polit Econ $14: 241-263$

Hayo B (2018) On standard-error-decreasing complementarity: why collinearity is not the whole story. J Quant Econ 16:1-19

Hayo B, Neuenkirch E (2018) The influence of media use on layperson monetary policy knowledge in Germany. Scott J Polit Econ 65:1-26

Hayo B, Neuenkirch M (2015) Self-monitoring or reliance on newswire services: how do financial market participants process central bank news? J Bank Finance 59:27-37

Hayo B, Neumeier F (2016) Survey on New Zealanders' Attitudes Towards and Knowledge of Macroeconomic Policy Issues: Documentation of Survey Methodology and Descriptive Results, MAGKS Joint Discussion Paper Series 30-2016, University of Marburg

Hayo B, Neumeier F (2021) Explaining central bank trust in an inflation targeting country: the case of the reserve bank of New Zealand. Oxf Econ Pap 73:27-48

Hayo B, Neumeier F (2020) Central bank independence in New Zealand: public knowledge about and attitude towards the policy targets agreement. J Bank Finance 113:105737

Higbee K (2001) Your Memory: How it Works and How to Improve It. Da Capo, Boston

Jappelli T (2010) Economic literacy: an international comparison. Econ J 120:429-451

Johannsen BK (2014) Inflation Experience and Inflation Expectations: Dispersion and Disagreement Within Demographic Groups, Finance and Economics Discussion Series 2014-089. Board of Governors of the Federal Reserve System, Washington

Karagedikli Ö, McDermott CJ (2018) Inflation expectations and low inflation in New Zealand. N Z Econ Pap 52:277-288

Kumar S, Afrouzi H, Coibion O, Gorodnichenko Y (2015) Inflation targeting does not anchor inflation expectations: evidence from firms in New Zealand. Brook Pap Econ Act 2:151-225

Lamla MJ, Lein SM (2014) The role of media for consumers' inflation expectation formation. J Econ Behav Organ 106:62-77

Lusardi A, Mitchell OS (2014) The economic importance of financial literacy: theory and evidence. J Econ Lit 52:5-44

Malmendier U, Nagel S (2016) Learning from inflation experiences. Quart J Econ 131:53-87

Mankiw NG (2015) Macroeconomics, 9th edn. Worth Publishers, New York

McDonald C (2017) Does Past Inflation Predict the Future? Reserve Bank of New Zealand Analytical Notes AN2017/04, Wellington

Moorman C, Diehl K, Brinberg D, Kidwell B (2004) Subjective knowledge, search locations, and consumer choice. J Consum Res 31:673-680

Nautz D, Strohsal T (2015) Are US inflation expectations re-anchored? Econ Lett 127:6-9

Norpoth H, Lodge M (1985) The difference between attitudes and nonattitudes in the mass public: just measurement? Am J Polit Sci 29:291-305

Parker M (2017) Price-setting behaviour in New Zealand. N Z Econ Pap 51:217-236

Ranyard R (2008) Foreword to the special section: perceptions and expectations of price changes and inflation. J Econ Psychol 29:375-377

Ranyard RF, Del Missier N, Bonini DD, Summers B (2008) Perceptions and expectations of price changes and inflation: a review and conceptual framework. J Econ Psychol 29:378-400

RBNZ (2017) Monetary Policy Statement August 2017, Reserve Bank of New Zealand, Wellington

Silverstone B (2014) Inflation Targeting in New Zealand: The 1987 Reserve Bank Survey Questionnaire and Related Documents, University of Waikato Working Paper in Economics 11/14

Sims CA (2003) Implications of rational inattention. J Monet Econ 50:665-690

Thomas LB (1999) Survey measures of expected U.S inflation. J Econ Perspect 13:125-144

Traut-Mattausch E, Schultz-Hardt S, Greitemeyer T, Frey D (2004) Expectancy confirmation in spite of discomforting evidence: the case of price increases due to the introduction of the euro. Eur J Soc Psychol 34:739-760

Van der Cruijsen CAB, Eijffinger SCW (2010) From actual to perceived transparency: the case of the European Central Bank. J Econ Psychol 31:388-399 
Van der Cruijsen CAB, Jansen D-J, de Haan J (2015) How much does the public know about the ECB's monetary policy? Evidence from a survey of dutch households. Int J Cent Bank 11:169-218

Van Lelyveld I (1999) Inflation or unemployment? Who cares? Eur J Polit Econ 15:463-484

Walstad WB (1997) The effect of economic knowledge on public opinion of economic issues. J Econ Educ 28:195-205

Wärneryd K-E (1986) The psychology of inflation. J Econ Psychol 7:259-268

White H (1980) A heteroskedasticity-consistent covariance matrix estimator and a direct test for heteroskedasticity. Econometrica 48:817-838

Williamson MR, Wearing A (1996) Lay people's cognitive models of the economy. J Econ Psychol $17: 3-38$

Woodford M (2003) Interest and Prices: Foundations of a Theory of Monetary Policy. Princeton University Press, Princeton

Zaller J (1992) The Nature and Origins of Mass Opinion. Cambridge University Press, Cambridge

Publisher's note Springer Nature remains neutral with regard to jurisdictional claims in published maps and institutional affiliations. 